九州大学学術情報リポジトリ

Kyushu University Institutional Repository

\title{
Registers of Reception: Audience and Affiliation in an Early Modern Shingon Ritual Performance
}

HAYES, MATTHEW

Department of Asian Languages and Cultures, University of California : Assistant Adjunct Professor

https://doi.org/10.5109/2794916

出版情報 : Journal of Asian Humanities at Kyushu University. 5, pp.1-16, 2020-03. Kyushu University, School of Letters, Graduate School of Humanities, Faculty of Humanities バージョン:

権利関係 : 


\title{
Registers of Reception: Audience and Affiliation in an Early Modern Shingon Ritual Performance
}

\author{
MATTHEW HAYES
}

\section{Introduction}

$\mathbf{T}$ he Shingon 真言 (literally “True Word" or "Mantra") school of Buddhism faced a crisis during the first few years of the Meiji era (1868-1912). In the wake of government mandates that severed lay affiliations with temples and anti-Buddhist movements that sought to "abolish Buddhism and destroy Śākyamuni” (haibutsu kishaku 廃仏毀釈), Shingon clerics fought to reconstitute their lay following. One approach to rebuilding this following emerged through an engaged proselytization that took place within ritual forums. Within the Chisan 智山 branch especially, ritual became one means of exposing laity to core doctrinal tenets through the chanting of Shingon verses and simplified explanations of Buddhist sutras. Clerics emphasized the crucial accessibility of de-elevated ceremonial content in reinvigorating relationships with the lay population.

Approximately ten years after the Meiji government dissolved the economic foundation that had long supported Buddhist temples of all sectarian divisions, Hattori Bankai 服部銭海 (1846-1909), a Shingon scholar-monk from Wakayama Prefecture, composed a step-by-step explanation of lay-oriented ceremonies of accessible import. ${ }^{1}$ On the function and purpose of two Japanese hymns (wasan 和讃) written by the medieval Shingon monk Kakuban 覺鋑 (1095-1143), one of which focuses on the assurance of a pacified mind (anjin 安心), he writes:

\footnotetext{
As for the meaning of the teachings of the secret True Word, they are extremely profound and subtle, and it is for this reason that necessarily clarifying [the teachings] for those of shallow wisdom is not easy. As for the difficulty and misapprehension of [the tenet of] anjin among our male and female lay companions, Tōji's abbot and great teacher Sanjū Nishijōzen [1844-1888] has lamented this. For the sake of quickly comprehending the tenets
}

I am grateful to Eric Tojimbara for his insight on early versions of this manuscript. I would also like to thank the editors of JAH-Q and an anonymous reviewer for their thoughtful and constructive remarks.

1 Hattori's explanations would later form the basis for the Chisan gongyō shiki 智山勤行式, a modern collection of ceremonies implemented by the Chisan branch in 1982 and now performed regularly at the Kyoto temple Chishakuin 智積院. The liturgies discussed in this article are no longer performed at Chishakuin. While several liturgical explanations circulated during the early Meiji period, Hattori's appears to have been more comprehensive in scope than most. For more on this text and its later iterations, see Sasaki, "Kinsei ni okeru 'Zaike gongyō hōsoku.'" 
of the secret tradition among male and female lay companions, he designates, based on the general meaning of the ritual commentaries, both the Shingon anjin wasan and Kōmyō Shingon wasan....

\section{祕密眞言の教意八、甚深微妙にして、淺智の者八 曉むべきこと容易ならざるが故に。在家男女の輩に 至て八、安心領解せんこと尤易ならざるを以て、東 寺一ノ長者三條西乗禪教正大に之を歎きいひ。在 家男女の輩をして、早く密宗の宗意を領解すること を得せしめんが為に經軌の旨趣に基づきて、眞言 安心と光明眞言との.... ${ }^{2}$}

Hattori's comments reflect both a growing concern over lay accessibility to Shingon teachings and the suitability of wasan in meeting those concerns. ${ }^{3}$ During the early Meiji period, the performance of wasan constituted one route toward rebuilding the lay religious community within the Shingon school due, in large part, to the genre's accessibility and simplicity before a lay audience.

While Hattori's injunction to leverage wasan in order to clarify core doctrinal tenets addressed a Meiji-era

2 Shingon shū zaike gongyō hōsoku wage 真言宗在家勤行法則和 解, pp. 13-14. Hattori does not name Kakuban as the author in this work, but Akatsuka Yūdō gives an overview of these wasan among others written by Kakuban in "Kōgyō Daishi wasan ni tsuite," pp. 61-63, and even mentions Hattori's injunction.

3 The remainder of Hattori's injunction appears as follows: This being the case, although any two wasan [can be performed] among the morning and evening services each day, in necessarily chanting one of these [above two examples] one can take command of their essential points and this ought to be the way of correctly understanding the tenet of anjin. This is most essential. Moreover, the lineage of these chanted [wasan] bring together the self-origination and the virtue of the five buddhas. If we consider the five notes on the pentatonic scale, the merits of directly voicing the syllables as reality are illuminated by chanting these wasan, and for those who lack knowledge, a mind laid to rest on the bed of insight into the same bodily form shared between the tathāgatas of five wisdoms, Mahāvairocana Akṣobhya, Ratnasaṃhhava, Amitābha, Amoghasiddhi, and Śākyamuni, is attained. Consequently, belief in this secret meaning and chants [of these wasan] will therefore increasingly extend one's merit to the brink. For especially this reason, we exceed this and meet the conditions and causes that made [these] wasan.

兩和讃を示しるひしとなれば日日朝暮勤行の砌に八、兩和讃の中何なりど も、其一を必唱へて、其旨趣を領知して、宗意安心を誤らざる様に致さる心゙ きこと。尤肝要なり。且唱ふる所の譜八、自然と五佛の徳に契ひたる。宮商 角徵羽の五音なれば、此和譛を唱ふる直聲字即實相の功徳に照らされ て、知らず識らず大日阿閦寶生彌陀釋迦の五智の如来と同體の覺悟の 床に安住することを得らる。因てからる秘旨あることを信して、唱ふれバ、功 徳ますます邊際なり。故にことに之を去るして、和讃を製しるひし所の縁由 を逑るのこと。 sectarian crisis of dwindling lay followers, Shingon clerics deployed similar tactics during earlier periods of relative comfort. This article reveals a continuous initiative to use ritual as a proselytizing forum for laity that stretched back to at least the Tokugawa era (1603-1868), during which Buddhist sectarian affiliation was a legal requirement. What follows is a comparative survey of two complementary liturgical performances that offered, on their own terms, access to core doctrinal tenets within the Chisan branch of Shingon Buddhism. Seventeenth- and eighteenth-century performances of Ceremonial Lecture on [the Merits of] Relic Offerings (Shari kuyō shiki 舎利供養式; hereafter Shari kōshiki) and Secret Hymn on Relics in Japanese (Shari himitsu wasan 舎利秘密和讃; hereafter Shari wasan), both written by Kakuban, provided alternative forums for doctrinal apprehension and devotional engagement during the same ritual sequence at Chishakuin 智積 院. ${ }^{4}$ While Buddha relics thematically anchored both of these liturgies and maintained a cohesive field of devotion during sequential performances, semantic and rhetorical modulations of their ritual language varied the targets of reception between lay and clerical audiences. The Shari kōshiki appeals to clerical imperatives to practice later became a scholarly focus of its principal exegete, Gahō 我寶 (1239-1317), and therefore finds its clerical audience in an upper register of reception. The Shari wasan, in its emphasis on lay-oriented practice and in its appeal to the active intervention of the Buddha's great compassion (daihi 大悲), finds its lay audience in a lower register of reception.

Performances of these liturgies at Chishakuin reveal that long before concerns over Meiji-era directives, Shingon clerics used wasan as a complementary and accessible ritual alternative for lay understanding. As a temple focused on karmic elimination (metsuzai 滅罪) rather than funerary services, Chishakuin became a site of ritual performance that met the soteriological concerns of its parishioners and, in the process, conveyed core Shingon doctrine through these two registers, or distinct levels of social, linguistic, and performative apprehensions of doctrinal knowledge. Above all, early

\footnotetext{
4 Kōshiki are a sub-category of a much larger genre of Japanese Buddhist chants (shōmyō 声明). They praise the merits of a central object of devotion, which may take the form of a buddha, bodhisattva, Buddhist text, founder figure, or other object. Wasan are devotional hymns typically composed in a 7-5 metered pattern and, like kōshiki, usually take a central object of devotion as their focus.
} 
modern performances of Kakuban's liturgies complicate our view of Shingon Buddhist ritual practice as socially partitioned insofar as they demonstrate the range with which ritual performance can communicate to and across varied groups of observers.

\section{Reception and Understanding in Religious Ritual}

This study builds on recent examinations of the relationship between ritual performance, textual production, and social partitions not only in Buddhist studies but also in medieval Christian studies. In his work on eighth-century sutra copying, Bryan Lowe reveals how such practices enjoined otherwise disparate classes and social groups and challenges our conception of Heianera (794-1185) textual practices as imperially centered. In doing so, he shows not only how ritualized engagements with texts cut across varied groups of Buddhists, but also how copyists engaged in world-building by leveraging the fluidity of liturgical genre. ${ }^{5}$ Asuka Sango, whose work illuminates the bilateral production of knowledge among clerics during the imperial assembly of ritual offerings [to the Sutra of Golden Light] (Misai-e 御齋會) in the Heian era, argues that bodies of knowledge were not only produced and preserved by the clergy, but that this knowledge was later refined within the context of ritual debate. ${ }^{6}$ Her study highlights the connectivity between sectarian identity and doctrinal positions in a ritual context and, ultimately, how clerics negotiated these positions in the face of sectarian challenges to orthodoxy. ${ }^{7}$ Abe Yasurō has suggested that ritual performers, commentators, and audience members each contributed to a matrix of production that grew out of medieval religious texts and that this production influenced the course of preaching (shōdō唱導) during later centuries. ${ }^{8}$ Similarly, Komine Kazuaki understands dharma assemblies as sites of religious literary

5 Lowe, Ritualized Writing

6 Sango, The Halo of Golden Light.

7 Beyond studies of Japan, Justin McDaniel has shown how, in modern Buddhist practice in Thailand, religious narratives operate meaningfully across social strata and that, critically, Thai Buddhist liturgy operates in the same way: ritual content is dynamic, fluid, public, and runs the spectrum of religious purpose across both lay and clerical communities. McDaniel, Lovelorn Ghost, pp. 121-60.

8 Abe, Chūsei Nihon no shūkyō, pp. 15-16. production that influenced the development of subsidiary liturgical genres, which include kōshiki. ${ }^{9}$ As each of these studies suggests, liturgical understanding can run bidirectionally between otherwise disparate social groups, and modes of Buddhist liturgical reception can range as widely as the rituals themselves.

In recent years, scholars of medieval Christianity have effectively given shape to the relationship between aural apprehension and meaning-making. In her study of female literacy in late medieval England, Katherine Zeiman argues that, through the body, lay women were able to perform liturgies that were otherwise unintelligible to them. ${ }^{10}$ She explores several fourteenth-century treatises on the expectations of liturgical mastery among female laity and argues for what she calls an embodied "liturgical literacy," or a mode of liturgical understanding from outside of the realm of discursivity and the intellect. The parameters of this literacy were not specified by those in places of literary or religious power, but instead depended on the inherent skills of the listener, namely musical, phonetic, mnemonic, and others grounded in the body. In stark distinction to the parameters defined by "grammatical culture," in which cultural elites take linguistic knowledge, especially grammar, as the central pole of understanding through oral communication, this type of literacy apprehends through visceral-as opposed to intellectual or affective-experience. ${ }^{11}$ Zeiman's study has opened new routes to exploring the interplay between ritual knowledge, performance, textual practices, and the role of the audience insofar as she takes seriously the role of corporeality in closing the perceived epistemological gaps that divide lay and clerical categories of religious belonging.

Similar to the case of women in late medieval England, the literate activities of contemporaneous lay Buddhists are rather difficult to assess. Kuroda Hideo has suggested connections between the rise of lateKamakura village documents and the proliferation of Buddhist temples as sites of literacy training. He concludes that basic training at these temple sites allowed some village leaders greater command over administrative tasks and their documentation. ${ }^{12}$ This medieval

\footnotetext{
9 Komine, Chūsei hō'e bungei ron, pp. i-viii.

10 Zeiman, "Reading, Singing, and Understanding."

11 For more on grammatical culture, see Irvine, The Making of Textual Culture, pp. 1-22.

12 See Kuroda, "Sengoku/Shokuhō-ki," p. 302.
} 
trend, also attested in the work of Richard Rubinger, continued in narrow form through the early Tokugawa years, whereby temples offered loose instruction in basic reading and writing to small cross-sections of the populace. ${ }^{13}$ Even later, more standardized curricula found at mid- and late-Tokugawa temple schools (terakoya 寺子屋) were largely delivered to novice monks, elite members of the samurai class, or to children of the wealthy. Very few townspeople, perhaps only those who required training tied to their livelihoods, accessed Buddhist education at these temples. Even then, popular literacy and its attendant disciplines (counting, history, and geography) generally comprised this type of education.

Regarding Buddhist material, therefore, it becomes challenging to make strong claims about the process of apprehension among laity. While Kakuban composed his Shari kōshiki in a Sino-Japanese hybrid style (wakan konkōbun 和漢混交文), clerics read it aloud in colloquial Japanese. Likewise, he originally composed his Shari wasan in colloquial Japanese for recitation. These linguistic features suggest an intended apprehension of the ritual language among attendees, though it does not necessarily suggest a comprehension of the ritual content. Yet, if we take as a general rubric Zeiman's emphasis on the body as a site of lay reception, as well as Hattori Bankai's attention to vocalization as a religious act grounded in the body for early-Meiji Buddhists, we can see how somatic impression lies at the core of ritual performance. ${ }^{14}$ All manner of sights, sounds, scents,

13 See Rubinger, Popular Literacy in Early Modern Japan, pp. 35-37.

14 In his exploration of "the archive" as a site of historical endurance, whereby statements are granted historical existence within a specific ruleset defined by the parameters of language, Foucault describes the construction of an epistemological substratum that quides both present and future historical positions. See Foucault, Archeology of Knowledge, pp. 41-63. Tyrus Miller argues for an extension of Foucault's model to ritual acts, during which speech repetition, bodily performance, and the presence of witnesses give shape to a sense event within theatrical time, the speech of which "may function as simulacra, affecting bodies, creating the turbulence of passion, projecting hypothetical experiences, generating phantasms, rising into appearance and passing into nothingness." See Miller, "Situation and Event," pp. 80-85. Ritual spaces therefore allow for the active and sustained production of meaning and understanding based, though not exclusively, on sensual apprehension. In a broader sense, David Morgan argues for the primacy of materiality in the initial experience of religious apprehension and suggests that such experience necessarily derives from physical symbols and corporeal sensation. See Morgan, Religion and Material Culture, pp. 5-9. and tactility indeed emerge during ritual performance and, in this way, offer inroads to sensual apprehension. ${ }^{15}$ These ever-present sensual processes are vital for knowledge acquisition since they are the frontlines between oneself and the material world. ${ }^{16}$

Michaela Mross, while recognizing that most $k \bar{o}$ shiki were not composed for the express purpose of lay participation, has nonetheless shown degrees of participation among laity during performances of the Shiza kōshiki 四座講式, written by Myōe 明惠 (1173-1232), which was comprised of performances of four isolated $k \bar{s}$ shiki, including his own version of the Shari kōshiki, related to the Buddha's final passing. ${ }^{17}$ Mross concludes that while communal chanting ensured a lay participation in medieval performances of koshiki, by the early modern period lay participation had essentially disappeared among Shingon performances. Most of the vocalization was performed by clergy while lay audiences listened. ${ }^{18}$ The implications of Mross's study are critical for the arguments here in at least two ways. First, they suggest that clergy had developed other means of

15 Considering the near-constant presence of burning incense during liturgical performance, scent was undoubtedly also at work during the ritual performances discussed in this article, though not, I would argue, as effective in communicating discursive knowledge regarding the content of a liturgy. According to Dan Sperber, who has written extensively on the relationship between knowledge and experience, scent has a wide and powerful "evocational field" to which individuals assign recollections and memories. Often, though, the recollections are more symbolically meaningful than the scent itself and, therefore, misdirect in the process of understanding. See Sperber, Rethinking Symbolism, pp. 15-23.

16 This is true from a Buddhist perspective, which emphasizes the primacy of causal process-physiological, ontological, epistemological, ethical, and so forth. According to Harvey Whitehouse, this is also true from a cognitive and evolutionary perspective; see Whitehouse, Modes of Religiosity, pp. 87-105. His theory of "doctrinal modes of religiosity" helps to bridge the gulf between ritual action and knowledge acquisition. He describes the transmission of knowledge during ritual acts, whereby high-frequency, low-arousal rituals tend to set the stage for the codification of an authoritative canon, the homogenization of a regional tradition, or the standardization of teachings and practices because of the collective reliance on ritual leaders skilled in routinized oration, dramatism, and systems of transmission. The religious knowledge transmitted during ritual, Whitehouse says, in following the early models of Stanley Tambiah, is highly motivating insofar as it is upheld as an authoritative truth that legitimizes collective understandings of social history. See Tambiah, Culture, Thought, and Social Action.

17 James Ford has also argued for degrees of lay participation within performances of kōshiki authored by Jōkei 貞慶 (1155-1213). Ford, "Competing with Amida."

18 Mross, "Vocalizing the Lament," pp. 122-23. 
engaging lay attendees during the performance of $k \bar{o}$ shiki by the early modern period, and while laity may not have joined in the communal chanting that had so often occurred during medieval performances, their presence during early modern performances was impelled by other factors. Second, her arguments leave open the possibility that we may also consider listening a form of participation.

Since the liturgical content of both the Shari $k \bar{o}-$ shiki and Shari wasan is largely transmitted through oral communication, I posit aural reception in ritual spaces as the primary mode of participation during performance at Chishakuin. It is impossible to determine with precision which aspects of doctrinal content were transmitted during the performance of the Shari koshiki and Shari wasan. And while some scholars have criticized ritual language as lacking any communicative power, one must recognize that language - although not exclusively - is one primary means of action that drives a ritual forward; language forms the core content of a liturgy, but it can also cue and pattern the structure of the ritual sequence itself. ${ }^{19}$ Even in instances where ritual language is disguised or deliberately misused, language is inherently communicative and performative. As Pascal Boyer describes in his work on tradition and meaning-making, ritual speech emerges through changes to linguistic morphology, consistent use of metaphorical repertoires, and the inclusion of foreign vocabularies meant to either widen or narrow meaning. ${ }^{20}$ In the present exploration of the Shari kōshiki and Shari wasan, which clerics performed in sequence usually in the small Founder's Hall (Kaisandō 開山堂) or larger Lecture Hall (Kōdō 講堂), I argue on the premise that the oral delivery of these rituals in varied spaces maintained a forum for reception among laity and clerics at Chishakuin. ${ }^{21}$

19 On this criticism, see Bourdieu, Language and Symbolic Power, pp. 84-85, and Wuthnow, Meaning and Moral Order, pp. 140-44. 20 Boyer, Tradition as Truth and Communication, pp. 79-82.

21 The erection of Chishakuin's original Founder's Hall began under the tenure of the temple's fourth abbot, Genju 元壽 (1575-1648), through modest donations made by followers. Land was granted in the southern Chishakuin precinct in 1665, on which expansions to the Founder's Hall began in 1667. This new expansion forms the basis of what stands at Chishakuin today, now referred to as the Mitsugondō 密嚴堂, and measures 122 square meters. See Chishakuin shi 智積院史, p. 158. Most of the Reception Hall was lost to fire in 1681, though the north gate was saved and used in the reconstruction of the building in 1685 . Since ancient times, this hall has also been used for ritualized doctrinal debates

(rongi 論議), and for this reason is also referred to as the Lecture

\section{Transmission, Accessibility, and Kakuban's Liturgies}

Early modern performances of the Shari kōshiki and Shari wasan were the result of a complex process of textual curation that developed during prior centuries. Below I survey the composition of these liturgies, situate them in the narrow context of Kakuban's textual lineage, and finally discuss their relationship to their respective liturgical genres.

Akatsuka Yūdō has traced the development of the various forms of the Shari kōshiki through the writings of Raiyu 賴瑜 (1226-1304), perhaps the most important figure in the formation of the Shingi Shingon 新義 眞言 school as it developed after Kakuban. ${ }^{22}$ Akatsuka surveys a section on the Shari kōshiki in Raiyu's bestknown work, Assorted Notes on Questions and Answers Concerning the True and Conventional (Shinzoku zakki mondō shō 眞俗雜記問答鈔), titled “On the Matter of the Mitsugon'in [Manuscript of] Shari kōshiki” (Mitsugon'in Shari kōshiki ji 密嚴院舎利講式事), wherein he describes two textual lines of the Shari kōshiki that grew out of terminological and structural differences created by later compilers. Raiyu cites the oral transmission (kuden 口傳) of Kyōōin 教王院, a temple of the Buzan branch (Buzanha 豐山派) located west of Kyoto, as the initial source of these lines of production and presents several critical points of inquiry regarding discrepancies between alternate versions of the Shari koshiki. ${ }^{23}$ The alternate versions of certain sections within the

Hall. Today's Lecture Hall measures approximately 645 square meters. See Chizan yōkō 智山瑤光, plate 4.

22 Akatsuka, "Kakuban no 'Shari kōshiki' o megutte."

23 For example, Raiyu claims that in the original manuscript the second and fourth sections of the liturgy surround praise to Tosotsu 兜率 (Sk. Tușita) and to the Dhāranī of the Seal on the Casket of the Secret Whole-body Relic of the Essence of All Tathāgatas (Issai nyorai shin himitsu zenshin shari hōkyōin darani kyō 一切如 來心祕密全身舍利寶䈄印陀羅尼經), respectively. This manuscript is presently held at Mitsugon'in 密嚴院 on Mount Kōya. In the Complete Collection [of the Works of] Kakuban (Kōgyō Daishi zenshū 興教大師全集), however, an alternate version of section two is rendered as praise for the secretly adorned Pure Land (Mitsugon jōdo 密嚴淨土) and, in the same section, praise for its highest joy (gokuraku 極樂). Likewise, an alternate version of section four appears as praise for the Mahāvairocana Sūtra (Dainichikyō 大日經) and, in the same section, praise for stupas (sotoba 率塔婆). See Akatsuka, "Kakuban no 'Shari kōshiki' o megutte," pp. 32 and 34. Interestingly, section four also includes praise to the Dhāranīi, as in the Mitsugon'in manuscript above, though it was composed on the reverse side (uragaki 裏書) of the original manuscript. Both versions of these sections appear sideby-side in modern prints of the Shari kōshiki. 
liturgy Raiyu describes were originally separate writings produced by Kakuban and added to this liturgy by later scholar-monks during the early process of compilation and reflect the will and whim of these later compilers.

The implications of Raiyu's discernment between the two versions of the Shari kōshiki bear on the present arguments in at least two ways. First, it suggests that widely-read versions of the liturgy, namely those now found in modern print versions of the Complete Collection [of the Works of] Kakuban (Kōgyō Daishi zenshu 興教大師全集), were the product of a curatorial process; the liturgy became part of a compilation based on conscious choices made by latter-day monks who had access to the two versions of the text. Critically, this "standard" version differs in content from Kakuban's original manuscript, now held by Mitsugon'in on Mount Kōya, the very mountain from which he was driven in 1141. Second, the presence of these two versions during the medieval period means that commentators also had to select their target texts and therefore contributed in their own conscious ways to the broader discourse surrounding relic power and worship in the medieval period. While I discuss the potential implications of commentarial choice in greater detail below, we can provisionally surmise that the Shari kōshiki enjoyed fairly wide use in the context of clerical study at Chishakuin during later centuries due to the circulation of several versions.

Kakuban composed the Shari kōshiki and Shari wasan as complementary liturgies and Suzuki Sanai has best treated them as such by identifying several corresponding passages. He describes wasan generally as a response to a rise in lecture-based liturgical practices, of which kōshiki are a part, and the slow rise of mass religious propagation. ${ }^{24}$ Similarly, Tsukudo Reikan has suggested that the medieval period brought several changes to religious perceptions and concerns among audiences. ${ }^{25}$ An increase in religious services oriented toward popular audiences (minshū 民衆) and the reductive qualities (kakōteki seishitsu 下降的性質) of such services, dually influenced by a rise of popular music and faith-based belief systems, flavored the composition of not only kōshiki of the time, composed by a bevy of influential religious figures such as Myōe, Shinran 親鸞 (1173-1262), and Jōkei 貞慶 (1155-1213), but

\footnotetext{
24 See Suzuki, "Kakuban saku no kōshiki," p. 115.

25 See Tsukudo, "Kōshiki no rekishiteki kōsatsu," pp. 7-15.
}

also of wasan. There are clear historical indications that new modes of accessibility began to pervade liturgical practice within the Shingon school during the Kamakura period (1185-1333) and, judging by the continued performance of both kōshiki and wasan across Buddhist schools through the early modern period and into the present day, these modes continue to hold value for lay and clerical ritual attendees.

There are constraints inherent to the wasan genre that require consideration in this appraisal of rhetorical and semantic style. Primarily, the structure of wasan typically follows a 7-5 syllabic meter, common to Japanese poetry, across four-line stanzas. ${ }^{26}$ This means that, in some cases, wasan authors may deploy certain isolated terms or turns of phrase in partial fulfillment of this structural requirement. While it is difficult, if not impossible, to determine whether or not Kakuban consciously used certain turns of phrase due, wholly or in part, to the metered constraints of the wasan genre in his composition of the Shari wasan, this possibility does not alter the fact that wasan are thematically and linguistically de-elevated works of praise. In other words, as a genre of praise delivered before audiences of all backgrounds, and as Itō Masahiro has shown, wasan, by definition, took the form of easy-to-understand songs of praise. ${ }^{27}$ While we can only examine the content of Kakuban's Shari wasan and judge the nature of reception through various corroborative materials below, the connection between the Shari wasan and Shari kōshiki suggests that the easy-to-understand portions of the Shari wasan were indeed meant to be easily understood. Kakuban's wasan, whether despite or due to the constraints of the genre, provided a rhetorically and semantically simplified version of his Shari kōshiki.

Below, I build on Suzuki's assertions surrounding the close relationship between the Shari kōshiki and Shari wasan by exploring at least two registers of reception inherent to both the textual and performative expressions of these liturgies. I show how rhetorical and semantic modulations of the ritual language in the Shari wasan expressed doctrinal tenets on a register attuned to lay practices and concerns. This mode of

\footnotetext{
26 Nakamura, Bukkyōgo daijiten, $1467 a$.

27 Itō explains how from the Heian period the usage of the term wasan became opposed to the elevated language in Chinese poetics (kansan 漢讃) and, by these means, wasan became associated with a relaxed syllabary (yawarakana 和らかな) for easy apprehension. See Itō, "Nihon bukkyō ni okeru wasan no yakuwari," pp. 800-801.
} 
apprehension allowed laity access to core facets of Shingon doctrine geared, in an upper register of reception, to a clerical agenda in the Shari kōshiki. I then contextualize these modes of reception among the social, spatial, and calendrical aspects of the performance of both liturgies at Chishakuin. Finally, I trace even later scholarly interactions with the Shari kōshiki among clerics at the temple.

\section{Rhetorical Variance}

Rhetorical variance, which I define as variations in logical complexity inherent to shared terms across each liturgy, provides a good, initial measure of the differences inherent to the Shari kōshiki and Shari wasan. In his Shari kōshiki, Kakuban follows major liturgical trends of esoteric relic worship in Japan by addressing the function of relics as vessels of the Buddha's great compassion and the potential reward for devotion directed toward them. ${ }^{28}$ Kakuban describes this function of relics in ascending levels of descriptive flourish and begins simply in the Pronouncement of Intention (hyobyaku 表白). This Pronouncement, which both forecasts the liturgical content to follow and frames the liturgy in broad devotional terms, lays out several basic statements surrounding the nature of relics, the Buddha, and the devotee:

In accordance with the innate desires [of each of you], [He] benefits living beings without bound. As a result, until having saved everyone, his Great Compassion does not rest and still lodges in His relics. Thus, in taking refuge [in His relics], one will necessarily cross over the ocean of three existences. In producing offerings [to them], one will certainly advance to the summit of four virtues [of enlightenment]. ${ }^{29}$

28 Asano Shōko, who has traced the thematic origins of this liturgy, suggests that the text may have been directly influenced by the Secret Ceremony on Dhātu [Relics] (Dato hishiki 駄都祕式), written by Kūkai 空海 (774-835), in which he describes the nonduality between Mahāvairocana and relics as a feature that allows for the receipt of benefits in the living world. See Asano, "Shari kōshiki shōko," pp. 110-11. For Kūkai's Dato hishiki, see Kōbō Daishi zenshū, vol. 14, p. 250

29 Kōshiki dētabēsu, text no. 40, lines 17-19.
隨其性欲、利生無邊。遂乃化縁已盡雖示滅度、 大悲不休、尚留舎利。適致歸依、必渡三有之海、 䌆興供養、定登四德之峯。

Several themes correspond with those in the sixth verse of Kakuban's Shari wasan:

Even though the teaching of his career-long mission has ended, and [he has] returned to the metropolis of four virtues [of enlightenment],

[His] Great Compassion and skillful techniques do not stop, but yet still lodge within relics. ${ }^{30}$

\section{一代化儀事終て \\ 四徳の都に的れども \\ 大悲方便止ずして \\ 舎利を留め置き給う}

In the greater context of each liturgy, these verses address slightly different concerns. The short passage from the Shari koshiki privileges the actions of the practitioner, who traverses the "peak of four virtues" after producing offerings to relics. ${ }^{31}$ In the Shari wasan, however, there is no mention of the actions of the practitioner. Instead, it is the Buddha who returns to the "city of four virtues" in the process of his final enlightenment (nyūmetsu 入滅). Yet his skillful techniques (hōben 方便), proffered through great compassion, remain lodged in relics. That is, Kakuban also includes here the means through which this compassion operates within the living world, and the means so often associated with the bodily form (shikishin 色身) of the Buddha, Sākyamuni.

The Shari wasan verse highlights an immediate access to great compassion through relics by appealing to the efficacy of the bodily form of the Buddha and his relics in the living world despite the perception of the

30 Kōgyō Daishi senjutsushū, vol. 2, p. 51.

31 As Ui Hakuju describes, the four virtues (shitoku 四德) appear in detail in the Nirvana sutra, which itself traces the time leading up to the passing of the Buddha. The four virtues include permanence or eternity (jōtoku 常德), joy (rakutoku 樂德), self-sovereignty (gatoku 我德), and purity (jōtoku 淨德). The Buddha urges others to foster these epistemological ideals in order to combat nihilistic views brought on by misunderstandings of emptiness. See Ui, Bukkyō jiten, p. 417. In this way, proper understanding becomes part and parcel of the Buddhist soteriological experience, and this quality is itself inherent to relics; the four virtues and the relics that symbolize the Buddha's embodiment of them are both symbols of proper epistemological understanding. 
Buddha's absence; the Buddha has returned to the "city of four virtues" and yet his corporeal fragments remain in the world as a source of great compassion. This verse emphasizes the skillful activities of the Buddha that, implicitly, enliven a faith and devotion among those seeking to access his great compassion..$^{32}$ The Shari kōshiki builds on this by adding injunctions to devotional practices meant to meet soteriological concerns.

Other passages more precisely reveal how Kakuban's embellished descriptions in the Shari kōshiki continue to highlight soteriologically contingent practices. On the issue of descriptive embellishment, Asano Shōko describes that in addition to the meritorious benefits reaped through the performance of the Shari koshiki, another purpose of the liturgy was to add descriptive and narrative power to the episode of the Buddha's final enlightenment, or the annihilation of his bodily form in the world. In contrast to the de-elevated characteristics we find in the Shari wasan, Asano highlights the complexity of not only Kakuban's Shari kōshiki, but also versions written by other clerics, as concurrent with the complex social features of relic belief (shari shinkō 舎利 信仰) during Japan's medieval era. ${ }^{33}$ That is, narrative flourish within kōshiki became one means of reflecting the growing faith surrounding relic power across both lay and clerical groups.

Kakuban expresses the depth and complexity of relic worship through embellished language in his Shari kōshiki:

Thus, the expounder of the True Word, the Great Sun Tathāgata, emerges from the supreme city of dharma bliss, courses through the gate of mutual empowerment, confers the jeweled carriage of spiritual penetration, and leads the confused to his Golden Site. In the end, he leaves relics among people and gods, and tours and proselytizes among the dharma realm. [By these means] the reverent

\footnotetext{
32 In prior scholarship on the primacy of faith and devotion in the Shari kōshiki, I show how the liturgy's principle exegete, Gahō, interpreted Kakuban's injunctions to practitioners to maintain a devotional relationship with relics. Part of Gahō's interpretation involves parsing key terms such as refuge (kie 㷌依), which he explains as related to faith and as an appropriate counter to the disorder (fun'un 紛紜) of existence in the three realms (Shari kuyō shiki shō 舎利供養式鈔, leaf 12). For more on the motifs of faith and devotion in Kakuban's Shari kōshiki and Gahō's commentary, see Hayes, "Faith, Devotion, and Doctrinal Knowledge," pp. 32-42.

33 See Asano, "Shari kōshiki shōkō," pp. 109-10.
}

will bound over deluded attachment in a single thought-moment. The faithful will verify [their own] Buddha cognition in their ordinary body. ${ }^{34}$

\section{是故眞言教主大日如來出法樂之都、趣加持之 門、授神通之寶輅、導迷情於金場。遂師留舎利 於人天、施化度於法界。仰者、一念超三劫、信 者、凡身證佛智。}

Here, Kakuban embellishes his articulation of the traversal of Mahāvairocana into the living world. These descriptions culminate with two acute references to the rewards of a practitioner's devotion: overcoming attachment and attaining buddhahood in one's ordinary body. In chapter 9 of another of his works, Esoteric Commentary on the Mantras of the Five Elements and Nine Seed-Syllables (Gorin kuji myō himitsushaku 五輪九字明祕密䆁), Kakuban attests to these soteriological rewards as particularly tuned to the program of practice among clerics. ${ }^{35}$ Nowhere in chapter 9 of his Esoteric Commentary does he claim a relationship between lay practice and the attainment of buddhahood in one's very body (sokushin jōbutsu 即身成仏). While he makes general claims for the primacy of faith and the efficacy of faith-based techniques in effecting enlightenment elsewhere in his works, the deliberate mention of present-body buddhahood in his Shari kōshiki connotes practices related to that particular soteriological goal.

This potential appeal to clerical concerns in this passage sharpens when read alongside corresponding verses from the Shari wasan that highlight the reward of merit, here in the seventh verse:

\footnotetext{
34 Kōshiki dētabēsu, text no. 40, lines 53-57.

35 For example, on the topic of attaining buddhahood in one's very body, Kakuban describes sets of practices meant for clerics of faculties tuned to Mahāyāna teachings (daiki 大機) or those tuned to mainstream (i.e., non-Mahāyāna) Buddhist teachings (shōki 小機). He delineates these faculties even further by sharpness and dullness (ridon 利鈍). He then furnishes among these four categories a range of appropriate practices-entering [through contemplation] the dharma realm essence (nyū hokkai taishō 入 法界體性), contemplation of the seed syllable A (aji kan ¥千 字観), and the gradual passage through the sixteen great bodhisattva stages (shidai ni oite jūroku dai bosatsu no i o heru 次第經於十六 大菩薩位), among others-that can effect buddhahood in one's very body. In other words, despite his delineation of faculties among practitioners, the practices best suited for attaining buddhahood in one's body are those that are cultivated through proper initiation and clerical training. T 2514, 21c03-22a16.
} 
[As for] companions who make offerings to and take refuge in [relics]

[They receive] the immeasurable blessings of meritorious virtue.

As for those who make offerings to the birth body [i.e., Sākyamuni],

Complete and perfect awakening is promised..$^{36}$

供養帰依の輩は

福德果報量りなし

生身供養為る人と

正等なりとぞ説給う

In the above verse, Kakuban draws a clear causal relationship, in two parallel couplets, between the act of giving offerings and the receipt of meritorious reward. He continues in this same vein in the following verse, but makes a soteriological pivot in the final couplet:

If one produces offerings on but one occasion, It will result in rebirth into the Heavens or liberation. If one contemplates the numerous genuine meanings, [Achieving] buddhahood in this very body will be possible. ${ }^{37}$

\section{一度供養を興ずれば \\ 生天解脱の因となる \\ 数々実義を観ずれば \\ 即身成仏難からず}

The first three couplets across both verses communicate the direct relationship between offerings and meritorious reward in simple terms. Companions (tomogara 輩) receive meritorious virtue through making offerings and taking refuge in relics, while those who make offerings to the living body (shōshin 生身; i.e., Sākyamuni's relics) receive similar benefits. In slight divergence from this pattern, Kakuban then describes a single offering as cause of rebirth in the Heavens. ${ }^{38}$ In full pivot, his final couplet describes the ease of realiz-

\footnotetext{
36 Kōgyō Daishi senjutsushū, vol. 2, p. 51.$$
37 \text { Ibid }
$$

38 While he does not delineate which, it is possible that he refers here to the Heaven of Merit Production (Fukushō ten 福生天) or Heaven of Extensive Rewards (Köka ten 廣果天), one of the ascendant Heavens of the form realm, described in the Discourse on the Stages of Contemplative Practice (Yuga shiji ron 瑜伽師地 論) as a destination attainable through repeated contemplative practice.
}

ing buddhahood in one's very body as a direct result of contemplative practice. Here, he positions buddhahood in parallel with long-established goals of seed-syllable (shūji 種子) contemplation outlined by Kūkai 空海 in his seminal works, especially The Meaning of the Syllable 'Hūm (Unjigi 吽字義). ${ }^{39}$ Thus, in distinction, the prior couplets highlight not only the practice of offerings, one of the penultimate lay-oriented practices, but also merit-making, the operative force in the lay soteriological program.

While the final mention of buddhahood in one's very body indicates the ideal culmination of clerical practice and indeed complicates our reading, it is proceeded by the rhetorical weight of sequential mentions of offering practices and their processes of merit-making. We must thus keep in mind that Kakuban composed the Shari wasan as a complement to the Shari $k o ̄ s h i k i$, which already orients itself toward clergy. As easy-to-understand hymns of praise delivered to a spectrum of attendees, the Shari wasan largely draws upon the major motifs of the Shari kōshiki, though alters its rhetorical complexity in order to de-emphasize the clerical imperatives to practice.

\section{Semantic Variance}

While the Shari kōshiki and Shari wasan differ rhetorically in their framing of the theme of potential blessings associated with relics, as well as how to access that potential, further pairings of passages highlight some of Kakuban's semantic strategies in representing the physical appearance of relics among human beings in different ways. I define these semantic variances as variations in the depth of meaning of similar or related terms across both liturgies. First, consider the following passage from the Shari kōshiki, which expresses both the visual and nondual features of Buddha relics:

$$
\begin{aligned}
& \text { The lotus body forged in Jambūnada gold is a } \\
& \text { charm of the dharma [body] Buddha in the sylla- } \\
& \text { ble A, [their] snowy jade emits a lunar glow, [their] } \\
& \text { ornamental pattern is the allure of the body, the } \\
& \text { purity and indestructibility [of these two bodies] } \\
& \text { are nothing other than the meaning of the Womb } \\
& \text { [Mandala], and [their] radiance and solidarity are }
\end{aligned}
$$

39 See, for example, T 2430, 404b17-404co8. 
nothing other than the meaning of the Diamond [Mandala]. Though transformed, all four bodies are actually one. ${ }^{40}$

\section{檀金錬蓮體、阿字法佛之姿、珂雪放月光、鋑文性} 身之色、清淨不壞、師胎藏之義、光明堅固、郎金 剛之意。縱局變化、既是四身隨一。

And sequential verses ten and eleven from the Shari wasan on the same topic:

Within the precious purple-gold lotus pedestal The original-ground dharma body manifests itself. The lunar glow of the white snowy jade washes over the form of the round ocean self-nature body.

Because this body pervades everywhere, the entire body and one iota of it do not differ. Because of the constancy of the dharma of the triple-world,

the birth body [of Śākyamuni] and [His] relics are

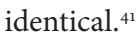

\section{紫磨金の蓮台に \\ 本地法身相現じ \\ 白珂雪の月光に

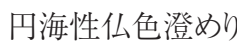

$$
\begin{aligned}
& \text { 編一切処の身なれば } \\
& \text { 全体一粒ことならず } \\
& \text { 常恒三世の法なれば } \\
& \text { 生身舎利一つなり }
\end{aligned}
$$

While each passage from the two liturgies above communicates the basic visual qualities and ontological implications of buddha relics, Kakuban's inclusion of semantic differences allow them to operate in two different registers. First, in the Shari kōshiki, Kakuban uses a reference to Jambūnada to describe the rarity and exquisiteness of the gold akin to the Buddha's lotus body (i.e., relics). Beyond this equality between a fine mineral and Buddha relics, Jambūnada refers to the trees that line rivers running through Jambudvipa, and the process of natural refinement of the gold within the riv-

40 Kōshiki dètabēsu, text no. 40, lines 114-18.

41 Kōgyō Daishi senjutsushū, vol. 2, p. 51. er. ${ }^{42}$ In the Shari wasan, however, the quality of value equal to gold is expressed much more simply through a synonymous reference to a highly prized gold of a purple tinge (shima ogon 紫磨黄金, here styled shima gon 紫磨金). This synonymous use does not carry the same referential and metaphorical weight as its mention of a specific Indian site and its narrative connotations in the Shari kōshiki. ${ }^{43}$

Second, in the Shari kōshiki, Kakuban presents the nondual features of relics through nested homologies, whereby relics stand in as the aspect (sugata 姿), form (shiki色), meaning ( $g i$ 義), and mind ( $i$ 意) for the absolute reality of the dharma body, which also includes, notably, the seed syllable $A$ so often mentioned in the context of contemplative practice throughout the rest of the liturgy. Accordingly, these five homological manifestations are primordially singular. While Kakuban makes a similar culmination at the end of the passage in the Shari wasan by positing the singularity of Buddha relics, he does so without the use of layered meaning and homology. Instead, by way of conditional verb endings, he strikes a causal relationship between realities of corporeality, the constancy of the dharma, and the singularity of relics. In this latter case, the relics in the world appear much more substantive and pervasive, whereas their appearance in the Shari kōshiki, while also conceptually akin to reality itself, is rhetorically obscured to listeners through the use of layered homological references.

The rhetorical and semantic differences outlined above suggest an alternative register of reception for lay attendees. The concision of the Shari wasan, in its appeal to long-popularized (as of the medieval period) reductive qualities, forces out much of the intensely referential and metaphorical perspective otherwise adopted by Kakuban in his Shari kōshiki. By way of descriptive flourish, Kakuban illustrates the routes to effective clerical practice in the Shari kōshiki.

\footnotetext{
42 Nakamura, Bukkyōgo daijiten, 121c. This gold, according to the Sūtra on Buddha Discourse on Buddha-Mother Precious Merit Storehouse Perfection of Wisdom (Busetsu butsumo shussan hōzō hannya haramitta kyō 佛説佛母出生法藏般若波羅蜜多經) is also likened to the appearance of the Buddha among the myriad living beings of the world.

43 Nakamura describes this purple-tinged gold as the best among this class of mineral, and notes that the use of suvarna ( "gold," "golden") in Sanskrit texts suggests that the glyph denoting the purple tinge was a later addition by translators. Nakamura, Bukkyōgo daijiten, p. 546b.
} 


\section{Performance at Chishakuin and Beyond}

In resonance with Zeiman's model of "liturgical literacy" outlined above, the aural faculties of lay practitioners made possible a reception of the textual content of the Shari wasan not through an appeal to grammatical, metaphorical, or overtly referential modes of communication but through an appeal to literacy tied to the reductive qualities of ritual language. Critically, both late-medieval and early-modern historical records show that clerics performed the Shari wasan and Shari kōshiki in direct sequence of one another during important festival periods at several Shingon temples. Within this social context, clerics enacted these textual differences through performance.

The Diary of Gien (Gien jugō nikki 義演准后日記), for example, details the social and religious contexts surrounding the performance of these liturgies at Daigoji 醍醐寺, one of the head temples of Kogi Shingon 古義真言. Gien's accounts span from 1595 to 1602 , across which there are at least twenty mentions of the Shari kōshiki performance. ${ }^{44}$ In at least five of these mentions, Gien makes clear that performances occurred concurrently with higan 彼岸, a festival period during which Buddhists engage in ancestral veneration during the spring and autumnal equinoxes.

Scholarly interpretations of the ritualistic aspects of higan vary widely, though Uranishi Tsutomu suggests that higan emerged as a Buddhist custom whereby ancestral veneration and prayer for productive agricultural harvests coincided in ceremony during the spring and autumnal equinoxes. ${ }^{45}$ Of early modern higan ceremonies, Nam-lin Hur points out that lay patrons of practically all Buddhist traditions gathered to chant the Buddha's name, and that temples also offered special sessions for preaching and sermonizing. ${ }^{46}$ Temples thus saw an influx of laypeople with the intent of observing or engaging in some manner of Buddhist service. ${ }^{47}$

While many of Gien's entries account for single

\footnotetext{
44 See Gien jugō nikki, vol. 1, pp. 3-5.

45 See Uranishi, "Higan'e," pp. 66-67. Nakamura, Bukkyōgo daijiten, $1121 a-b$, similarly suggests that while the predominant purpose of higan assemblies was ancestral veneration, it also allowed for respite from the toil of daily work.

46 See Hur, Death and Social Order, p. 189

47 Earlier accounts, such as those of Mansai 滿濟 (1378-1435; Mansai jugō nikki 滿濟准后日記, vol. 1, pp. 341, 395), also composed at Daigoji, situate the Shari kōshiki performance amid additional ritual contexts such as New Year's celebrations, Buddhist lectures, celebrations for the Buddha's birthday, and chanting.
}

performances on a single day, one entry stands out for its duration. From the third through the eighth day of the second month of 1602, Daigoji clergy performed the Shari kōshiki on a variety of successive occasions. We also find mention of the performance of the Shari wasan, here styled Relic Hymn (Dato san 駄都讚), directly following the performance of Kakuban's Shari $k \bar{s}$ shiki. ${ }^{48}$ If we take a wide view of this ritual calendar, Gien's accounts paint a vivid picture of equinoctial performance and attendance at Daigoji: clergy and laity comingled during the events of higan and bore witness to the performance of the Shari wasan, which immediately followed the performance of the Shari koshiki. In this way, the grouping of these performances underscores how audience composition emerged in step with performances of rhetorically and semantically variant liturgies at Daigoji during the early seventeenth century.

We find similar performances during later years within the Shingi Shingon school at Chishakuin. Chishakuin's status of metsuzai temple is important in the following consideration of rituals conducted during the seventeenth and eighteenth centuries because it communicates both the types of rituals most offered to patrons as well as the voluntary basis on which patrons witnessed them. As opposed to funerary patrons (sōshiki danna 葬式檀那 or sōshiki danka 葬 式檀家), for whom funerary and memorial rites were delivered by clerics of an affiliated temple, prayer patrons (metsuzai danna 滅罪檀那, lit. "karmic elimination patron,” often styled 滅罪旦那) witnessed rituals focused on the receipt of this-worldly benefits (genze riyaku 現世利益), including protection from disaster and malady, prosperity, and longevity. ${ }^{49}$ These patrons remained connected to the temple through voluntary

48 Gien jugō nikki, vol. 1, p. 68; vol. 2, p. 4. Steven Trenson details the medieval development of relic rites (dato hō 駄都法), which acted as liturgical templates for a variety of devotional rituals that take central objects of devotion. These objects ranged, as he says, from various buddhas and bodhisattvas, to texts and even grains of rice. See Trenson, "A Study on the Combination of the Deities," p. 119.

49 Meiji shonen jiin meisaichō 明治初年寺院明細帳 (p. 24, plate 52) gives a narrow sense of where Chishakuin stood in terms of danna 檀那 holdings in the late seventeenth and early eighteenth centuries. This record lists 110 metsuzai danna holdings still tied to Chishakuin during the early Meiji, a time during which the government had begun stripping affiliations in the name of decentralizing Buddhist power blocs amid temple networks. 
affiliations. ${ }^{50}$ In the case of Chishakuin, patrons actively sought out the benefits enacted by rituals, many of which, as described above, coincided with other socio-religious events hosted by Chishakuin.

History of Chishakuin (Chishakuin shi 智積院史) gives an account of the performance of the Shari kōshiki and Shari wasan that is rather similar to those of Gien. ${ }^{51}$ These accounts represent, more importantly, drastic changes to the liturgical program at the temple at the beginning of the eighteenth century. According to four activity records (gyōji roku 行事録) that span from 1751 to 1848 , the ritual program at Chishakuin began to focus on ritual forms of a devotional and expiatory nature, namely through the performance of the Mantra of Light (Kōmyō shingon 光明眞言), which offered witnesses potential longevity along with the removal of karmic hindrances and illnesses through the recitation of honorable names ( $h \bar{o} g \bar{o}$ 寶號) of buddhas and bodhisattvas and dedications of merit (eko 迴向).$^{52}$ This liturgical development indicates a movement toward a ritual program with target audiences oriented toward the benefits of a metsuzai temple. Moreover, this movement also falls in line with Hattori Bankai's above injunction to include the Kōmyō Shingon wasan as part of a renewal effort to combat dwindling lay followers within the Shingon school more generally.

A year-round calendar built from a composite of these four activity records accounts for this new liturgical orientation. During the second month, Chishakuin offered the performance of the Jōraku-e 常樂會, a broader ritual sequence focused on devotional chanting and during which clerics sequentially performed the Shari kōshiki, Shari wasan, and Verse [Paying Homage to] Relics (Shari raimon 舎利礼文)..$^{53}$

During the fourth month, clerics performed the Shari kōshiki during assemblies for the Buddha's birthday (Butsu tanjō-e 佛誕生會). Both of these events

50 See Ambros, "Clerical Demographics in the Edo-Meiji Transition," pp. 86-87.

51 See Chishakuin shi, pp. 385-86

52 The four activity records are Hōreki nenchū gyōji 寶暦年中行事, An'ei nenchū gyōji 安永年中行事, Kyōwa ganryō nenchū gyōji roku 享和岸寮年中行事録, and Kaei Chisan nenchū gyōji 嘉永智山 年中行事 (Chishakuin shi, p. 392).

53 The Shari raimon is a short verse extolling the virtue of the Buddha Sākyamuni and the continued presence of that virtue in relics. The authorship of this verse remains unclear, though many scholars attribute it to either Amoghavajra (705-774), Yixing 行 (683-727), or Śubhakarasiṃha (637-735). See Ishikawa, "Shari raimon ni tsuite," pp. 650-51. began with offerings made before the image of Sākyamuni at the north altar of the Reception Hall. Clerics delivered the Shari kōshiki again during the seventh month, and accounts make specific mention of patchwork robes (sōgyari 僧伽梨) donned for the express purpose of large, public gatherings of the entire religious community. ${ }^{54}$ This final account makes also makes specific mention of the accompaniment of a range of karmically expiatory ceremonies mentioned above. ${ }^{55}$

The architectural, liturgical, and calendrical details that emerge in Chishakuin's own early modern history indicate that clerics delivered the Shari kōshiki and Shari wasan during socially-inclusive events similar to that of higan at Daigōji, which brought laity and clerics together in devotional spaces across the temple precincts. Events such as the Jöraku-e and Butsu tanjō-e drew religious adherents to Chishakuin in order to express devotion through ceremony and, at the same time, receive the benefits from several expiatory ritual forms. The aural experience of these ceremonies in the varied ritual spaces of the Founder's Hall and the Lecture Hall became one mode of reception for laity; they could hear, through vocalization of a modulated ritual language, of the centrality of relics in effecting the Buddha's great compassion in the world. Clerics, in vocalizing such content, expressed their devotion in the same ritual context.

\section{The Shari kōshiki and Clerical Learning}

The medieval Shingon exegete Gahō is the chief commentator on Kakuban's Shari kōshiki and completed his commentary, titled Shari kuyō shiki shō, sometime between the years 1294 and 1309. Both its content and early modern reproductions at the hands of Kakugen 覺眼 (1643-1722), the eleventh abbot of Chishakuin, provide further suggestion that the Shari kōshiki was tuned for clerical concerns. Kakugen's lead role in educational reform during the very year of the reproduction of this commentary highlights his attention to Kakuban's liturgy as a text of scholastic potential in the context of monastic education.

In the late seventeenth century, Chishakuin issued major changes to curricula at Shingi Shingon monastic

54 See Nakamura, Bukkyōgo daijiten, 874c.
55 See Chishakuin shi, pp. 386-92. 
schools (danrin 談林). The monk Ryūkō 隆光 (16491724), who at the time was head of the Buzan temple Murōji 室生寺, chronicled the sweep of new changes to systems of Buddhist learning at Shingon temples. One major change was the ritual and educational integration of the Hōon $k \bar{o}$ 報恩講, a twice-yearly liturgy commemorating the teachings of Kakuban, into Shingi Shingon danrin curricula. ${ }^{56}$ With this change, monks were expected to prepare for the performance of the Hōon ko through study, and to participate in the ritual, itself punctuated by bouts of intense study. Later in Ryūkō's same chronicle, he describes the Hōon kō as involving training in vocal chanting (shōmyō 声明), esoteric rituals (jissō 事相), Siddham (Shittan 悉量), non-Buddhist texts (kaiten 外典), and other topics. ${ }^{57}$ This overall re-systematization of Shingi Shingon danrin curricula meant a reinforcement of foundational Buddhist learning through the integration of an educational liturgy centered on the discourse of Kakuban.

Chishakuin shi reveals both a conceptual and calendrical intimacy between the Hōon kō, Kakuban's Shari kōshiki, and Kakugen's efforts to publish Gahō's commentary in $1696 . .^{8}$ First, it corroborates Ryūkō's account that Chishakuin was tasked with the management of the continuity of the teachings (hōru shihai 法流支 配) across all Kanto-area danrin. As a head temple, this meant ample control over Shingi Shingon curricula well beyond the Kyoto region. Second, the accounts attest that in 1693, at the start of Yūgan's 宥鏑 (16241702) tenure as ninth abbot at Chishakuin, Kakugen left the temple to train for the specific rank of judge (seigisha 精義者). This rank would grant him power to set standard procedure for discourse and discussion of the essential teachings (hōyō rondan 法要論談) that stemmed from Chishakuin, especially in rituals meant for clerical advancement, such as the Denbō dai-e 傳法

\footnotetext{
56 The Hōon kō is performed across many Buddhist schools and generally expresses devotion and gratitude toward the Buddha or a founder figure for their dissemination of their teachings in the world. The Shingi Shingon Hōon kō (originally called Kakuban kō 覺鋊講) likely began in performance for Kakuban in 1344, according to the Sukusō shū 束草集, dated the same year. See Sakaki, "Shingi Shingon no rongi," p. 196. Clerics typically performed the Hōon kō twice yearly, during the summer and winter, through the end of the Edo period. After the start of the Meiji period, Shingon temples performed only the winter Hōon kō on a yearly basis. See Nakajima, "Takaosan Rakuō in no danrin saikō," pp. 151-52.

57 Jissō is used commonly in esoteric contexts to refer to ritual practice, as opposed to doctrinal study, or kyōsō 教相.

58 See Chishakuin shi, pp. 137-38, 404-405.
}

大會. Kakugen was granted this title in 1696, making him, and his temple, major stewards of Shingi Shingon danrin curricula at the time. Kakugen's subsequent publication of Gahō's Shari kōshiki shō that very year meant that he had effectively published an exegetical work in direct complementarity with the new uniform requirements at danrin under Chishakuin's control and, moreover, one that highlights the discourse of Kakuban to which clerics directed their commemoration during the Hōon kō. Chishakuin attests to this ritual circularity in its own history, where we find the Hōon kō and the Shari kōshiki, two liturgies notable for their direct connections to Kakuban, carried out in calendrical sequence with one month and eight days of overlapping time. ${ }^{59}$ This indicates the lasting impression of Kakugen as expositor in setting new standards of procedure that addressed changing curricular concerns.

In key areas across his two-fascicle commentary, Gahō seizes upon the scholarly potential in the Shari kosshiki by focusing on the etymology of the word shari and, through nested metaphor drawn from the work of Kükai, themes of nonduality. Critically, he also stakes a claim in the very purpose of the Shari kōshiki, which is to highlight one of Kakuban's core doctrinal positions: the incorporation of faith into rigorous practice. Across the entire commentary, he deepens an otherwise complex presentation of Shingon relic worship by building upon the explanatory mechanisms within the liturgy: he meets metaphor with metaphor, cites extensively, and assumes of his reader a broad understanding of Buddhist doctrine. Engagements with the Shari kōshiki in this upper register of reception are further corroborated by visual clues within Kakugen's 1696 print, namely wide, upper margins (jōran 上欄) in place for note-taking. Meiji-era reprints of this commentary also contain ample symbolic scholia, an indication that Gahō's commentary was also used in even later forums of study. ${ }^{60}$

\footnotetext{
59 In a section titled "Various Dharma Assemblies" (Sho hōe 諸法 會) the account details the ritual schedule from the first to the last month of 1761. That year, the summer Hōon kō began on the first day of the third month and ended on the sixteenth day of the fifth month. That same year, the performance of the Shari kōshiki began on the eighth day of the fourth month and ended on the eighth day of the seventh month. See Chishakuin shi, pp. 386-90.

60 The reprint in my possession contains symbolic scholia across twenty-six pages (eleven pages in the first volume and fifteen pages in the second volume).
} 


\section{Conclusion}

The performance of wasan as communicative and proselytizing opportunities appears to have had precedent long before Hattori Bankai composed his injunction to "take command of their essential points" during the Meiji era. His encouragement to utilize wasan in public rituals in order to reconstitute the Shingon following would later become the foundation of liturgical schedules in the Chisan branch generally. This, above all, is a testament to Hattori's keen eye in identifying wasan as an accessible genre for modern times.

While scholars have explored this accessibility in medieval contexts, the performance of Kakuban's Shari wasan at Chishakuin gives us a glimpse of its utility centuries later, though before Hattori's injunction to perform them. As for the Shari kōshiki, as evidenced by exegetical and editorial engagements at Chishakuin, it remained a liturgy of observable scholarly import long after its composition. The fact that the Shari koshiki and Shari wasan were performed in direct sequence of one another indicates not only that the devotional aspects of the kosshiki and wasan genres allowed for such performative complementarity, but also that this devotion brought clerics and laity together within the same ritual space.

The content across these liturgies indicate that relic power and worship was common ground among their mixed audiences. With the development of the early modern system of temple affiliation, of which metsuzai temples like Chishakuin were a part, relics satisfied desires for blessings in the world. The ritual performances of the Shari koshiki and Shari wasan cut through these mixed audiences and offered, on different registers, a forum to apprehend messages of the proximity of the Buddha's body as a source of great compassion.

\section{Reference List}

\section{- Abbreviation Used}

$\mathrm{T}$ Taishō shinshū daizōkyō 大正新修大藏經. 100 vols. Ed. Takakusu Junjirō 高楠順次郎, Watanabe Kaigyoku 渡邊 海旭 et al. Taishō Issaikyō Kankōkai, 1924-1934.

\section{- Primary Sources}

Chishakuin shi 智積院史. Comp. Kōbō Daishi Onki Jimukyoku 弘法大師遠忌事務局. Kyoto: Chishakuin, 1934.

Chizan yōkō 智山瑤光. Comp. Kōbō Daishi Onki Jimukyoku. Kyoto: Chishakuin, 1933.

Gien jugō nikki 義演准后日記. Gien 義演. 2 vols. Comp. Yanaga Teizō 弥永貞三 et al. Zoku Gunsho Ruijō Kanseikai, 1976-2006.

Gorin kuji myō himitsushaku 五輪九字明祕密釋. Kakuban 覺鉞. T 2514.

Kōbō Daishi zenshū 弘法大師全集. Comp. Sofū Sen’yōkai 祖風宣揚会. 16 vols. Yoshikawa Kōbunkan, 1923.

Kōgyō Daishi senjutsushū 興教大師撰述集. Comp. Miyasaka Yūshū 宮坂宥勝. 2 vols. Sankibō Busshōrin, 1977.

Kōgyō Daishi zenshū 興教大師全集. Comp. Nakano Tatsue 中野達慧 and Tomita Kōjun 富田斆純. 9 vols. Sesōken, 1935.

Mansai jugō nikki 滿濟准后日記. Mansai 滿濟. 2 vols. Comp. Kyōto Teikoku Daigaku Bunka Daigaku 京都 帝國大學文科大學. Kyoto: Rokujō Kappan Seizōjo, 1918-1920.

Meiji shonen jiin meisaichō 明治初年寺院明細帳. 2008. Vol. 7. Comp. Tamamuro Fumio 圭室文雄. Aruhīfu.

Shari himitsu wasan 舎利秘密和讃. Kakuban. In Kōgyō Daishi senjutsushū 興教大師撰述集, comp. Miyasaka Yūshō 宮坂宥勝, pp. 50-53. Sankibō Busshorin, 1977. Shari kuyō shiki 舎利供養式. Kakuban. Comp. Nakano Tatsue and Tomita Kōjun. In Kōgyō Daishi zenshū, vol. 2, pp. 1281-93. Sesōken, 1935.

Shari kuyō shiki shō 舎利供養式鈔. Gahō 我寶. Rare Books Collection, Taisho University, Tokyo.

Shingon shū zaike gongyō hōsoku wage 真言宗在家勤行法 則和解. Hattori Bankai 服部鋑海. Doki Hōryū, 1881.

Sukusō shū 束草集. Comp. Fujita Tsuneyo 藤田経世. Kōkan Bijutsu Shiryō. 1952.

Unjigi 吽字義. Kūkai 空海. T 2430.

Yuga shiji ron 瑜伽師地論. Trans. Xuanzang 玄奘. T 1579.

\section{- Secondary Sources}

Abe Yasurō 阿部泰郎. Chūsei Nihon no shūkyō tekusuto taikei 中世日本の宗教テクスト体系. Nagoya Daigaku Shuppankai, 2013. 
Akatsuka Yūdō 赤塚祐道. “Kakuban no 'Shari kōshiki' o megutte” 覺鋑の「舎利供養式」をめぐって. Indogaku bukkyōgaku kenkyū 印度學佛教學研究 61:1 (2012), pp. 12-20.

Akatsuka Yūdō. “'Kōgyō Daishi wasan’ ni tsuite”『興教大師 和讃』について. Heian bukkyō gakkai nenpō 平安仏教学 会年報 8 (2014), pp. 61-73.

Ambros, Barbara. "Clerical Demographics in the Edo-Meiji Transition: Shingon and Tōzanha Shugendō in Western Sagami.” Monumenta Nipponica 64:1 (2009), pp. 83-125.

Asano Shōko 浅野祥子. “Shari kōshiki shōkō” 舎利講式 小考. Bukkyō bunka gakkai kiyō 佛教文化学会紀要 1 (1997), pp. 109-19.

Bourdieu, Pierre. Language and Symbolic Power. Oxford: Polity Press, 1991.

Boyer, Pascal. Tradition as Truth and Communication: A Cognitive Description of Tradition Discourse. Cambridge University Press, 1990.

Ford, James. "Competing with Amida: A Study and Translation of Jōkei’s Miroku Kōshiki.” Monumenta Nipponica 60:1 (2005), pp. 43-79.

Foucault, Michel. Archeology of Knowledge. London: Routledge, (1969) 2003.

Guelberg, Niels. Kōshiki dētabēsu 講式データベース (defunct as of 9/29/2019). http://www.f.waseda.jp/guelberg/ koshiki/datenb-j.htm.

Hayes, Matthew. "Faith, Devotion, and Doctrinal Knowledge: Interpretive Strategies in Shingon Liturgical Exegesis." Journal of Religion in Japan 7 (2018), pp. 27-56. Hur, Nam-lin. Death and Social Order in Tokugawa Japan: Buddhism, Anti-Christianity, and the Danka System. Harvard University Press, 2007.

Itō Masahiro 伊藤真宏. “Nihon bukkyō ni okeru wasan no yakuwari” 日本仏教における和讃の役割. Indogaku bukkyōgaku kenkyū 40:2 (1992), pp. 800-802.

Irvine, Martin. The Making of Textual Culture: 'Grammatica' and Literary Theory 350-1100. Cambridge University Press, 1994.

Ishikawa Ryōiku 石川良昱. “Shari raimon ni tsuite” 舎利禮 文について. Indogaku bukkyōgaku kenkyū 22 (1963), pp. 650-54.

Komine Kazuaki 小峯和明. Chūsei hō-e bungei ron 中世法 会文芸論. Kasamashoin, 2009.

Kuroda Hideo 黒田日出男. “Sengoku/Shokuhō-ki no gijutsu to keizai hatten” 戦国·織豊期の技術と経済発展. In Kōza: Nihon rekishi 4: Chūsei 2 講座: 日本歴史四: 中世 二, ed. Rekishi Kenkyūkai 歴史学研究会 and Nihon Shi Kenkyūkai 日本史研究会, pp. 275-315. Tokyo Daigaku Shuppankai, 1985.
Lowe, Bryan. Ritualized Writing: Buddhist Practice and Scriptural Cultures in Ancient Japan. University of Hawai i Press, 2017.

McDaniel, Justin. The Lovelorn Ghost and the Magical Monk: Practicing Buddhism in Modern Thailand. Columbia University Press, 2011.

Miller, Tyrus. "Situation and Event: The Destinations of Sense." In Ritual and Event: Interdisciplinary Perspectives, ed. Mark Franko, pp. 75-90. New York: Routledge, 2007.

Morgan, David, ed. Religion and Material Culture: The Matter of Belief. New York: Routledge, 2010.

Mross, Michaela. "Vocalizing the Lament Over the Buddha's Passing: A Study of Myōe's 'Shiza kōshiki." Japanese Journal of Religious Studies 43:1 (2016), pp. 89-130.

Nakajima Tami 中島田美. “Takaosan Rakuō in no danrin saikō to Hōon kō ni tsuite” 高尾山楽王院の談林再興 と報恩講について. In Kinsei Takaosanshi no kenkyū 近 世高尾山史の研究, ed. Murakami Tadashi 村上直, pp. 135-76. Meicho Shuppan, 1998.

Nakamura Hajime 中村元. Bukkyōgo daijiten 佛教語大辞 典. Tokyo Shōseki, 1975.

Rubinger, Richard. Popular Literacy in Early Modern Japan. University of Hawai'i Press, 2007.

Ruppert, Brian. Jewel in the Ashes: Buddha Relics and Power in Early Medieval Japan. Cambridge: Harvard University Asia Center, 2000.

Sakaki Yoshitaka 榊義孝. “Shingi Shingon no rongi” 新義真 言の論議. In Rongi no kenkyū 論議の研究, ed. Chisan Kangakkai 智山针学会, pp. 185-222. Seishi Shuppan, 2000.

Sango, Asuka. The Halo of Golden Light: Imperial Authority and Buddhist Ritual in Heian Japan. University of Hawai' $i$ Press, 2015.

Sasaki Daiju 佐々木大樹. “Kinsei ni okeru 'Zaike kingyō hōsoku’ no seiritsu to kōzō” 近代における「在家勤行法 則」の成立と構造. Gendai mikkyō 現代密教 22 (2011), pp. 229-59.

Sperber, Dan. Rethinking Symbolism. Trans. Alice L. Morton. Cambridge University Press, 1975.

Suzuki Sanai 鈴木左内. “Kakuban saku no kōshiki to sono kanren wasan” 覚銭作の講式とその関連和讃. In Bukkyo bungaku kenkyū 仏教文学研究, ed. Bukkyō Bungaku Kenkyūkai 仏教文学研究会, pp. 115-33. Kyoto: Hōzōkan, 1969.

Tambiah, Stanley. Culture, Thought, and Social Action: An Anthropological Perspective. Harvard University Press, 1985.

Trenson, Steven. "A Study on the Combination of the Deities Fudō and Aizen in Medieval Shingon Esoteric 
Buddhism." In Buddhist Encounters and Identities Across East Asia, ed. Ann Heirman, Carmen Meinart, and Christoph Anderl, pp. 108-36. Leiden: Brill, 2018.

Tsukudo Reikan 筑土鈴寬. “Kōshiki no rekishiteki kōsatsu” 講式の歴史的考察. In Tsukudo Reikan chōsaku shū: Dai san kan, chūsei, shūkyō geibun no kenkyū 筑土鈴寬著作: 第三卷、中世·宗教藝文の研究, pp. 7-26. Serika Shobō, 1976.

Ui Hakuju 宇井伯壽, ed. Bukkyō jiten 佛教辭典. Daitō Shuppansha, 1989.

Uranishi Tsutomu 浦西勉. "Higan-e: Minkan ni okeru higan no fūshū” 彼岸会 : 民間における彼岸の風習. In Bukkyō nenchū gyōji 仏教年中行事, vol. 6, of Bukkyō minzokugaku taikei 仏教民俗学大系, ed. Itō Yuishin 伊 藤唯真, pp. 65-78. Meicho Shuppan, 1986.

Whitehouse, Harvey. Modes of Religiosity: A Cognitive Theory of Religious Transmission. New York: Altamira Press, 2004.

Wuthnow, Robert. Meaning and Moral Order: Explorations in Cultural Analysis. University of California Press, 1987.

Zeiman, Katherine. "Reading, Singing, and Understanding: Constructions of the Literacy of Women Religious in Late Medieval England." In Learning and Literacy in Medieval England and Abroad, ed. Sarah Rees Jones, pp. 97-120. Turnhout: Brepols, 2003. 